\title{
Porcine circovirus 2 and 3 in wild boars in Southern Brazil
}

\author{
Ana Carolina Dal Santo ${ }^{1}$ (i) Leticia Trevisan Gressler ${ }^{2}$ (D) Samay Zillmann Rocha Costa ${ }^{3}$ \\ João Rogério Centenaro ${ }^{2}$ (D) Isabella Mazzocato Dazzi ${ }^{2}$ Mathias Martins $^{1,4^{*}}$ (D)
}

${ }^{1}$ Laboratório de Virologia, Medicina Veterinária, Programa de Pós-gradução em Sanidade e Produção Animal, Universidade do Oeste de Santa Catarina (UNOESTE), Xanxere, SC, Brasil

${ }^{2}$ Laboratório de Imunologia e Microbiologia Veterinária, Instituto Federal Farroupilha (IFFar), Frederico Westphalen, RS, Brasil..

${ }^{3}$ Laboratório de Patologia Veterinária, Instituto Federal Farroupilha (IFFar), Frederico Westphalen, RS, Brasil.

${ }^{4}$ Department of Population Medicine and Diagnostic Sciences, College of Veterinary Medicine, Cornell University, Ithaca, 14853, NY, USA, E-mail: mm3245@cornell.edu. 'Corresponding author.

ABSTRACT: Porcine circovirus 2 (PCV2) has a considerable economic impact on the pork industry worldwide for more than two decades. In 2016, a new circovirus, porcine circovirus 3 (PCV3), was described; since then, it has been reported to be associated with diseased or even in clinically healthy swine in several countries. Considering the importance of wild boars as reservoirs of swine pathogens and the extensive distribution of these animals in Rio Grande do Sul and throughout the national territory, we searched for PCV2 and PCV3 in twenty-six wild boars coupled with necropsy and histologic examination of the sampled animals. Using PCR, 182 tissue samples were analyzed, including the heart, kidneys, liver, lung, lymph nodes, spleen, and tonsils. PCV2 and PCV3 were detected in 57.7\% (15/26) and 15.4\% (4/26) of wild boars, respectively. Furthermore, co-infection with PCV2 and PCV3 was detected in one of these animals, with PCV2 or PCV3 DNA detection in multiple organs. Histological examination showed mild to moderate and multifocal lymphoplasmacytic interstitial nephritis distributed randomly throughout the renal cortex, apparently unrelated to PCV2 or PCV3 detection. The wild boar population in Brazil is extensive, indicating the presence of a larger number of swine pathogen hosts. In the present study, more than half of the wild boars harbored PCV2; and although less frequently, PCV3 was also detected. Therefore, free-living wild boars can serve as reservoirs of swine circoviruses in southern Brazil.

Key words: circoviruses, PCV3, porcine circovirus reservoir, wild boar.

Circovírus suíno 2 e 3 em javalis no Sul do Brasil

RESUMO: O circovírus suíno 2 (PCV2) tem causado impacto econômico na indústria suína em todo o mundo por mais de duas décadas. Em 2016, um novo circovírus foi descrito - circovírus suíno 3 (PCV3) - e desde então tem sido relatado em vários países associado a doenças ou mesmo suínos saudáveis. Diante da importância dos javalis como reservatórios de patógenos suínos, e da ampla distribuição desses animais no Rio Grande do Sul e em todo o território nacional, foi realizada pesquisa de PCV2 e PCV3 em vinte e seis javalis (10 fêmeas e 16 machos). Necropsia e exame histológico foram realizados. Utilizando PCR, foram analisadas 182 amostras de tecidos incluindo: coração, rins, fígado, pulmão, linfonodos, baço e tonsila. PCV2 e PCV3 foram detectados por PCR em 57,7\% (15/26) e 15,4\% (4/26) dos javalis, respectivamente. Um destes animais estava co-infectado por PCV2 e PCV3. O DNA do PCV2 ou PCV3 foi detectado em multiplos órgãos. No exame histológico foi observada nefrite intersticial linfoplasmocitária multifocal leve a moderada, distribuída aleatoriamente pelo córtex renal, aparentemente sem relação com a detecção de DNA viral. A população de javalis no Brasil é extensa, resultando em maior número de hospedeiros para patógenos de suínos. No presente estudo, mais da metade dos javalis capturados abrigavam PCV2 e, embora menos frequente, PCV3 também foi detectado. Os javalis de vida livre podem servir como reservatórios de circovírus suínos no sul do Brasil.

Palavras-chave: circovirus, javalis, $P C V 3$, reservatório de circovírus.

\section{INTRODUCTION}

Wild boars (Sus scrofa scrofa) are present in 22 of the 27 Brazilian States, including Rio Grande do Sul, the southernmost state of Brazil (BRASIL,
2019). This species is susceptible to several pathogens with the potential for transmission to domestic pigs, and these animals may act as a disease reservoir (MENG; LINDSAY, 2009). Wild boars can act as a wild host to several viruses, including three species 
of porcine circoviruses: porcine circovirus 1 (PCV1), porcine circovirus 2 (PCV2), and porcine circovirus 3 (PCV3) (PRINZ et al., 2019).

Porcine circovirus, belonging to the family Circoviridae and the genus Circovirus, with is the smallest virus with a circular, ambisense, singlestranded DNA genome of about 1770 to $2000 \mathrm{bp}$ (ICTV, 2019). PCV1 was discovered in the 1970s as a contaminant of cell cultures and, to date, has not been associated with disease (HAMEL et al., 1998). Meanwhile, PCV2 has been associated with a wide range of clinical manifestations in domestic pigs for more than two decades (SEGALÉS et al., 2013). In contrast, PCV3 was described in 2016 (PALINSKI et al., 2017; PHAN et al., 2016), and has been reported in swine from several countries, including Brazil (DAL SANTO et al., 2020; RODRIGUES et al., 2020; SARAIVA et al., 2019; TOCHETTO et al., 2018). Since then, PCV3 has been associated with several pathological disorders, such as stillbirths (ARRUDA et al., 2019; DAL SANTO et al., 2020; SAPORITI et al., 2020), cardiac and multi-systemic inflammation (PHAN et al., 2016; TEMEEYASEN et al., 2021), porcine dermatitis and nephropathy syndrome (PDNS)-like disease, and reproductive failure (ARRUDA et al., 2019; DAL SANTO et al., 2020; PALINSKI et al., 2017), and can even be reported in healthy domestic pigs and wild boars (FRANZO et al., 2018; STADEJEK et al., 2017). Although, the pathogenesis of PCV3 has not been fully studied, it has been reproduced in pigs experimentally infected with PCV3 (JIANG et al., 2018; TEMEEYASEN et al., 2021). Another study performed the first isolation of PCV3 from perinatal and reproductive failure cases in the United States and characterized the infection by experimental inoculation of PCV3 isolate in cesarean-derived, colostrum-deprived pigs (MORADÍAZ et al., 2020).

In Brazil, some studies have reported the occurrence of PCV3 in commercial swine farms. PCV3 was detected in Brazilian frozen and formalinfixed paraffin-embedded swine tissues from 1967 to the 2010s (RODRIGUES et al., 2020). Another study, which included samples of swine fetuses from 11 commercial farms from five Brazilian States, reported approximately $97 \%$ of mummified fetuses positive for PCV3 (DAL SANTO et al., 2020). In wild boar, according to our knowledge, there is only one study in Brazil that describes PCV3 detection on this species using samples obtained between the years 2013 and 2015 (VARELA et al., 2020).

To increase our knowledge of the presence of circovirus in the wild boar population, this study indentified PCV3, along with PCV2, in wild boars caught in Southern Brazil.

\section{MATERIALS AND METHODS}

\section{Animals and sample collection}

Twenty-six wild boars (10 females and 16 males) were slaughtered through the official program of wild boards population control, in Alegrete ( $n$ $=16)$ and Quaraí $(n=10)$ municipalities, West of Rio Grande do Sul (RS) State, Brazil (Figure 1). The samples were collected in collaboration with monitoring agents of wild boars, which operate in RS State in accordance with Normative Instruction 03 of January 31, 2013. Tissue samples from the heart, kidneys, liver, lung, and lymph nodes (parotid, mediastinal, mesenteric, and inguinal lymph nodes were pooled together, resulting in a unique sample), and spleen and tonsils were collected and stored in sterile bags and transported under refrigeration for up to $72 \mathrm{~h}$. At the laboratory, the tissues were fragmented into small pieces, from different sides, and aliquoted into $2 \mathrm{~mL}$ microtubes for freezing at $-20{ }^{\circ} \mathrm{C}$.

\section{Necropsy, sampling, and histologic examination}

The standard necropsy technique was adapted so that the hunters could keep the carcasses after the procedure. Following external examination and the opening of body cavities, the thoracic and abdominal viscera were exposed and evaluated grossly. Tissue samples from the heart, kidneys, liver, lung, spleen, tonsil, stomach, and intestine were fixed in a $10 \%$ formalin solution. In the laboratory, the tissues were processed according to routine procedure, and stained with hematoxylin and eosin. The slides were then examined under a light microscope.

\section{DNA extraction and PCR}

A total of 182 tissue samples were collected from the twenty-six wild boars. DNA extraction was performed using BIOPUR silica column (BIOPURTM Kit de Extração Mini Spin Plus, Biometrix Diagnóstica Ltda, Curitiba, PR, Brazil) following the manufacturer's instructions. Tissues $(100 \mathrm{mg})$ from different organs were macerated individually using scalpel blades, homogenized in phosphate-buffered saline (PBS) solution at a weight-to-volume ratio of $1: 10$, and clarified by centrifugation $(5000 \mathrm{~g}$ for $5 \mathrm{~min}$ ), after which the supernatant was stored at $-20^{\circ} \mathrm{C}$. DNA extraction was performed using $200 \mu \mathrm{L}$ of supernatant.

Conventional PCR amplification was used for the detection of PCV3 (PALINSKI et al., 2017) and PCV2 (RINCÓN MONROY et al., 


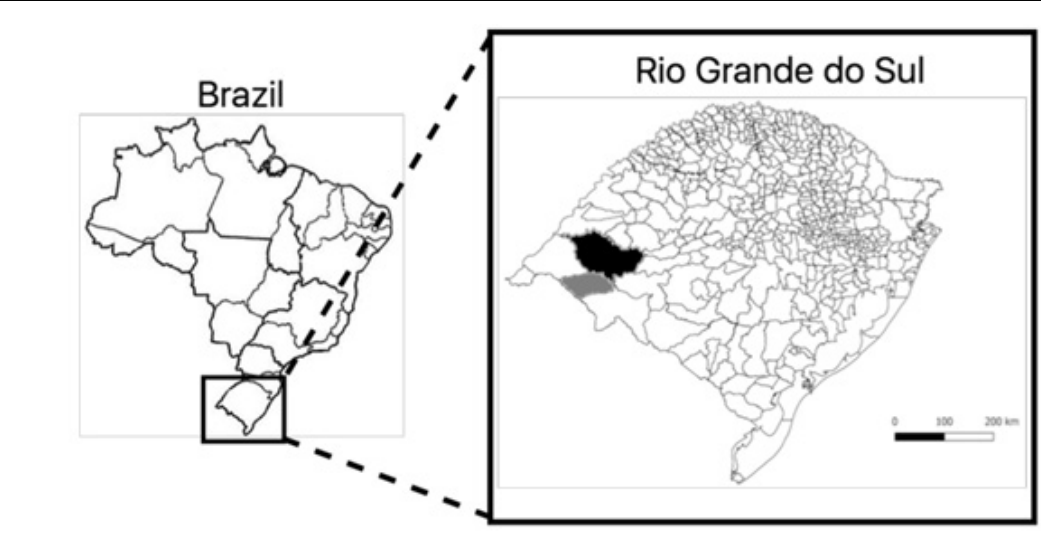

Figure 1 - Map of Brazil. The black rectangle highlights Rio Grande do Sul State, the southernmost state of Brazil. In the magnified image, is highlighted Alegrete (hatched area in black) and Quaraí (hatched area in grey), municipalities where the wild boars were hunted.

2014), as previously reported. The primers forward $5^{\prime}<$ GCCAGTTCGTCACCCTTTC $>3$ ' and reverse $5^{\prime}<$ CTCCCGCACCTTCGGATAT $>3$ ', and forward $5^{\prime}<$ CCACAGAAGGCGCTATGTC $>3$ ' and reverse 5 ' $<$ CCGCATAAGGGTCGTCTTG $>3$ ' were used for PCV2 and PCV3 PCR, respectively. For both reactions targeting an internal region of the capsid gene $(O R F 2)$, and an amplicon of 659 and $330 \mathrm{bp}$ for PCV2 and PCV3, respectively. The PCR amplification was carried out in a $25 \mathrm{ul}$ reaction containing $12.5 \mu \mathrm{L}$ of $\mathrm{GoTaq}^{\circledR}$ Green Master Mix, 2X (Promega, Madison, WI, USA) (DNA Polymerase, reaction buffer ( $\mathrm{pH} 8.5$ ), $400 \mu \mathrm{M}$ dATP, $400 \mu \mathrm{M}$ dGTP, $400 \mu \mathrm{M} \mathrm{dCTP}, 400 \mu \mathrm{M}$ dTTP, and 3 $\left.\mathrm{mM} \mathrm{MgCl}_{2}\right), 2 \mu \mathrm{L}$ of sample, and $10.5 \mu \mathrm{L}$ nucleasefree water. The DNA was then denatured at $95^{\circ} \mathrm{C}$ for $5 \mathrm{~min}$, followed by 35 cycles of denaturation, annealing, and extension $\left(94^{\circ} \mathrm{C}, 50{ }^{\circ} \mathrm{C}\right.$, and $72{ }^{\circ} \mathrm{C}$, respectively), followed by a final $10 \mathrm{~min}$ extension at $72{ }^{\circ} \mathrm{C}$; positive PCV2 and PCV3 samples from our previous study were used as positive controls (DAL SANTO et al., 2020). Nuclease-free water was used as a non-template control. PCR amplicons were separated by agarose gel electrophoresis, using a 1\% agarose gel stained with intercalating DNA UniSafe Dye (Uniscience do Brasil, Sao Paulo, SP, Brazil), and the gels were viewed by an imaging system under UV light after electrophoresis.

\section{RESULTS AND DISCUSSION}

PCV2 and PCV3 were detected in $57.7 \%$ $(15 / 26)$ and $15.4 \%(4 / 26)$ of the wild boar samples, respectively. The representative electrophoresis picture showing the positive amplification of PCV2 and PCV3 alongside their respective molecular weight markers is shown in the figure 2. The distribution of PCV2 and PCV3 according to animal identification and organ sampling is presented in table 1 , and the percentage of positivity is shown in figure 3. Co-infection with PCV2 and PCV3 was detected in one animal (M5/ lung). Importantly, this is the first report of co-infection of PCV2 and PCV3 in a wild boar in Brazil.

Parasitic infections were the primary gross and microscopic findings. In four wild boars (M7, M8, M10, and F6), histological examination showed mild to moderate and multifocal lymphoplasmacytic interstitial nephritis distributed randomly in the renal cortex, apparently unrelated to PCV2 or 3 infection. The four wild boars that presented interstitial nephritis in our study were negative for PCV3, and two of them were PCV2 positive (F6/lung and M8/tonsil) (Table 1).

We reported a low rate of PCV2 and PCV3 co-infection $(3.8 \% ; 1 / 26)$ in wild boars, similar to findings previously published, and the overall coinfection rates at the case level were low (8.4\%) (WANG et al., 2020). These authors believe that PCV2 and PCV3 may act as individual pathogens in majority of infections, which is in line with the ability of PCV3 to cause PDNS-like clinical disease in piglets following PCV3 experimental infection (JIANG et al., 2018; TEMEEYASEN et al., 2021). However, further studies are necessary to elucidate whether there is an interference between each other epidemiology and immunopathogenesis, considering PCV2 and PCV3 co-infection in a host. 

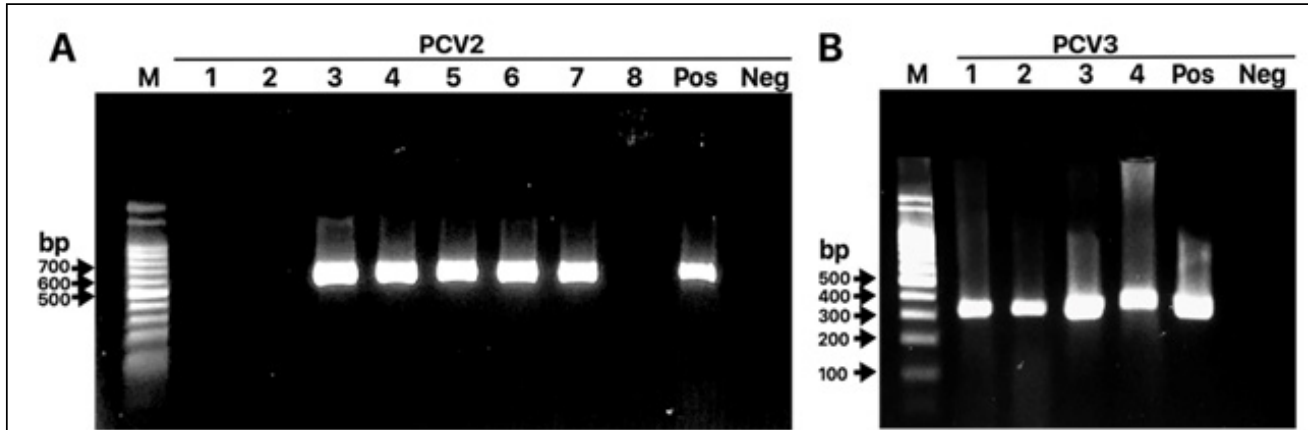

Figure 2 - A - Agarose gel after polymerase chain reaction (PCR) and amplification of an internal region of the gene encoding the capsid protein (ORF2) of porcine circovirus 2 (PCV2). Amplicon of 659 base pairs (bp). Samples 3, 4, 5, 6, and 7 are positive, while samples 1, 2, and 8 are negative. B - Agarose gel after PCR and amplification of an internal region of the gene encoding the capsid protein $(O R F 2)$ of porcine circovirus 3 (PCV3). Amplicon of 330 bp. Samples 1, 2, 3, and 4 are positive. $M=$ molecular weight standards (100 bp ladder). Pos = positive control. $\mathrm{Neg}=$ negative control.

Based on the results reported here, PCV3 has tropism for a wider range of cell types, which are probably causing animals more susceptible to infection. The PCV3 ability to affect different anatomical sites has been described in a study with an extensive number of cases occurring in the United States, causing reproductive failure, encephalitis, and myocarditis in perinatal piglets, as well as porcine dermatitis, nephropathy syndrome, and periarteritis in domestic swine (ARRUDA et al., 2019). Previous studies have reported several histological changes associated with the infection by PCV3 in pigs, including

Table 1 - Molecular detection of porcine circovirus 2 (PCV2) and porcine circovirus 3 (PCV3) in wild boars according to organ sampled. Sampled animals showed at least one of their tissues is positive with PCV2 and/or PCV3.

\begin{tabular}{|c|c|c|c|c|c|c|c|}
\hline \multirow[t]{2}{*}{ Animal ID } & ---- & - n---- n & ----- & ---tiss & ------------------' & --------- & -------- \\
\hline & heart & kidney & liver & lung & lymph nodes ${ }^{*}$ & spleen & tonsil \\
\hline $\mathrm{F} 1$ & & & & $+1-$ & $+1-$ & & \\
\hline $\mathrm{F} 2$ & $+1-$ & $+/-$ & & & & & \\
\hline F3 & & & & $+1-$ & & & \\
\hline $\mathrm{F} 4$ & $+/-$ & $+/-$ & & & & & \\
\hline F6 & & & & $+1-$ & & & \\
\hline F7 & & $+1-$ & & & & & \\
\hline F8 & $+1-$ & & & & & & \\
\hline F9 & & $+1-$ & & & & & \\
\hline F10 & & & & & & & $+1-$ \\
\hline M1 & $+1-$ & & & $+1-$ & $+1-$ & & \\
\hline M2 & & $+1-$ & & & & & \\
\hline M4 & $+1-$ & & & & $+/-$ & $+/-$ & \\
\hline M5 & & & & $+1+$ & & $-1+$ & $-1+$ \\
\hline M6 & & & & & & & $-1+$ \\
\hline M8 & & & & & & & $+1-$ \\
\hline M9 & $+/-$ & $+/-$ & & $+1-$ & & $-1+$ & $+1-$ \\
\hline M16 & & $-1+$ & & $-1+$ & & $-1+$ & \\
\hline
\end{tabular}

$\mathrm{F}=$ female; $\mathrm{M}=$ male; $+/-=$ PCV2 positive and PCV3 negative; $-/+=$ PCV2 negative and PCV3 positive; +/+ = PCV2 and PCV3 positive.

Ciência Rural, v.52, n.2, 2022. 


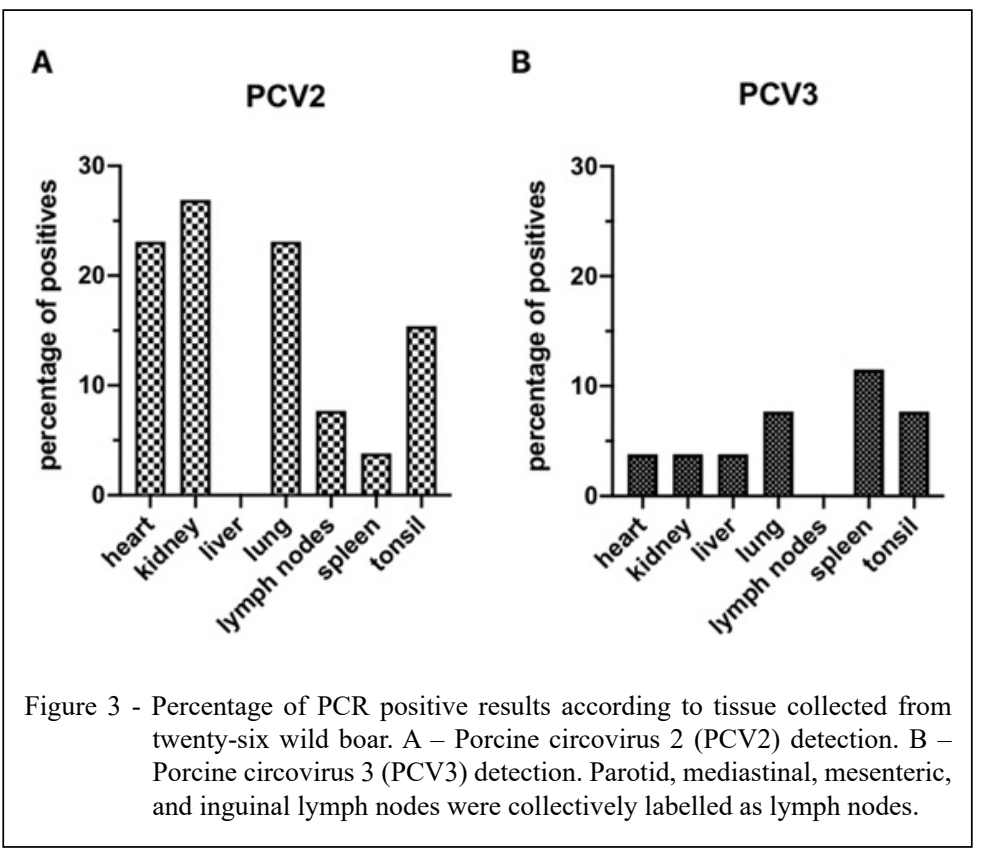

lymphoplasmacytic and histiocytic broncho-interstitial pneumonia, depletion and necrosis of lymphoid tissue, with or without histiocyte proliferation in the lymph nodes (JIANG et al., 2018; KEDKOVID et al., 2018; PHAN et al., 2016), and chronic arterial damage in the heart, kidneys, and liver (ARRUDA et al., 2019; PHAN et al., 2016; TEMEEYASEN et al., 2021). However, none of the PCV3 positive wild boars in our study were presented with any microscopic changes. In addition, the wild boars did not show signs that could be associated with PCV infection. However, even in domestic swine, infection with PCV2 and PCV3 can occur without apparent clinical disease (SEGALÉS, 2012; STADEJEK et al., 2017). Additionally, a serological survey performed in Italy revealed high titers of antibodies against PCV3 (approximately 30\%) in apparently healthy wild boars (FRANZO et al., 2018). Likewise, none of the 26 wild boars we evaluated presented histologic changes compatible with PCV2 infection. Expected PVC2 lesions include lymphoid tissue depletion, occasional histiocytic proliferation in lymph nodes, and lymphoplasmacytic and histiocytic inflammation in various organs (FENAUX et al., 2002).

The occurrence of PCV2 and PCV3 in wild boars may be an additional challenge for commercial pig production. Considering that both viruses have been detected, the potential risk of pathogen transmission between wild boars and domestic pigs must be considered; therefore, biosecurity measures on commercial pig farms must be ensured so that wild boars are kept away from farms. Although, PCV2 has been widely reported in Brazil, more studies on the epidemiology and pathogenesis of PCV3 in wild boars are needed.

\section{CONCLUSION}

Facing the emergence of new pathogens with high potential to cause diseases, we reinforce the importance of epidemiological screening of wild boars. Since there are a large number of freeliving wild boars in Brazil, it is essential to monitor the occurrence of pathogens in these populations. Herein, we described the occurrence of PCV2 and PCV3 in wild boars in Southern Brazil, including a case of co-infection.

\section{DECLARATION OF CONFLICT OF INTEREST}

The authors declare no conflict of interest. The founding sponsors had no role in the design of the study; in the collection, analyses, or interpretation of data; in the writing of the manuscript, and in the decision to publish the results.

\section{BIOETHICS AND BIOSSECURITY COMMITTEE APPROVAL}

The present study was approved by the Ethics Committee on Animal Experimentation of the Farroupilha Federal 
Institute (CEUA), Rio Grande do Sul (RS), Brazil, protocol number 3256260617.

\section{ACKNOWLEDGMENTS}

The authors thank the Programa de Pós-graduação em Sanidade e Produção Animal, Universidade do Oeste de Santa Catarina (UNOESC), Xanxere, SC, Brazil, for their support. Ana Carolina Dal Santo was supported by the Programa de Bolsas Universitárias de Santa Catarina (UNIEDU). We also acknowledge the Fundação de Amparo à Pesquisa do Estado do Rio Grande do Sul (FAPERGS), Brazil, for financial support (process n. 7/2551-0000900/ARD-2017) and Instituto Federal Farroupilha for providing us a scientific initiation scholarship and financial support. The study was financed in part by the Coordenação de Aperfeiçoamento de Pessoal de Nível Superior (CAPES), Brasil - Finance code 001.

\section{AUTHOR CONTRIBUTIONS}

Conceptualization: MM; Methodology: LTG, MM; Sample acquisition: JRC, ID, SZRC, LTG; Sample analysis: ACDS, MM, SZRC. Writing original draft: LTG, MM; Writing, review and editing: LTG, MM; Funding acquisition: LTG, MM; Resources: LTG, MM; Supervision: LTG, MM.

\section{REFERENCES}

ARRUDA, B. et al. PCV3-associated disease in the United States swine herd. Emerging Microbes and Infections, v.8, p.684-698, 2019. Available from: $<$ https://www.tandfonline.com/doi/full/10 $.1080 / 22221751.2019 .1613176>$. Accessed: Mar. 15, 2021. doi: $10.1080 / 22221751.2019 .1613176$.

BRASIL, Ministério de Agricultura, Pecuária e AbastecimentoMAPA. Defesa Sanitária Animal-DSA, 2019. Available from: $<$ https:// www.gov.br/agricultura/pt-br/assuntos/sanidade-animal-e-vegetal/ saude-animal/programas-de-saude-animal/arquivos-programassanitarios/PercepodaocorrnciadesunosasselvajadosMAPA2019.pdf. png/view>. Accessed: Mar. 15, 2021.

DAL SANTO, A. C. et al. Full-genome sequences of porcine circovirus 3 (PCV3) and high prevalence in mummified fetuses from commercial farms in Brazil. Microbial Pathogenesis, v.141, p.104027, 2020. Available from: <https://www.sciencedirect.com/ science/article/pii/S088240101932056X > Accessed: Mar. 15, 2021. doi: 10.1016/j.micpath.2020.104027.

FENAUX, M. et al. Cloned genomic DNA of type 2 porcine circovirus is infectious when injected directly into the liver and lymph nodes of pigs: characterization of clinical disease, virus distribution, and pathologic lesions. Journal of Virology, v.76, p.541-551, 2002. Available from: <https://jvi.asm.org/ content/76/2/541.short>. Accessed: Mar. 15, 2021. doi: 10.1128/ JVI.76.2.541-551.2002.

FRANZO, G. et al. First report of wild boar susceptibility to porcine circovirus type 3: high prevalence in the Colli Euganei Regional Park (Italy) in the absence of clinical signs. Transboundary and Emerging Diseases, v.65, p.957-962, 2018. Available from: $<$ https://onlinelibrary.wiley.com/doi/abs/10.1111/tbed.12905>. Accessed: Mar. 15, 2021. doi: 10.1111/tbed.12905.

HAMEL, A. L. et al. Nucleotide sequence of porcine circovirus associated with postweaning multisystemic wasting syndrome in pigs. Journal of Virology, v.72, p.5262-5267, 1998. Available from: <https://jvi.asm.org/content/72/6/5262.short>. Accessed: Mar. 15, 2021. doi: 10.1128/JVI.72.6.5262-5267.1998.

ICTV. International committee on taxonomy of viruses. Available from: <https://talk.ictvonline.org>. Accessed: Apr. 21, 2021.

JIANG, H. et al. Induction of porcine dermatitis and nephropathy syndrome in piglets by infection with porcine circovirus type 3 . Journal of Virology, v.93, p.1-16, 2018. Available from: $<$ https:// jvi.asm.org/content/93/4/e02045-18.abstract>. Accessed: Mar. 15, 2021. doi: 10.1128/JVI.02045-18.

KEDKOVID, R. et al. Porcine circovirus type 3 (PCV3) infection in grower pigs from a Thai farm suffering from porcine respiratory disease complex (PRDC). Veterinary Microbiology, v.215, p.71-76, 2018. Available from: <https://www.sciencedirect.com/ science/article/pii/S0378113517312609>. Accessed: Mar. 15, 2021. doi: 10.1016/j.vetmic.2018.01.004.

MENG, X. J.; LINDSAY, D. S. Wild boars as sources for infectious diseases in livestock and humans. Philosophical Transactions of the Royal Society B: Biological Sciences, v.364, p.2697-2707, 2009. Available from: <https://royalsocietypublishing.org/doi/ abs/10.1098/rstb.2009.0086>. Accessed: Mar. 15, 2021. doi: 10.1098/rstb.2009.0086.

MORA-DÍAZ, J. et al. Isolation of PCV3 from perinatal and reproductive cases of PCV3-associated disease and in vivo characterization of $\mathrm{PCV} 3$ replication in $\mathrm{CD} / \mathrm{Cd}$ growing pigs. Viruses, v.12, p.1-21, 2020. Available from: <https://www.mdpi.com/19994915/12/2/219>. Accessed: Mar. 15, 2021. doi: 10.3390/v12020219.

PALINSKI, R. et al. A novel porcine circovirus distantly related to known circoviruses is associated with porcine dermatitis and nephropathy syndrome and reproductive failure. Journal of Virology, v.91, p.e01879-16, 2017. Available from: <https://jvi. asm.org/content/91/1/e01879-16>. Accessed: Mar. 15, 2021. doi: 10.1128/JVI.01879-16.

PHAN, T. G. et al. Detection of a novel circovirus PCV3 in pigs with cardiac and multi-systemic inflammation. Virology Journal, v.13, p.1-8, 2016. Available from: <https://virologyj.biomedcentral. com/articles/10.1186/s12985-016-0642-z>. Accessed: Mar. 15, 2021. doi: 10.1186/s12985-016-0642-z.

PRINZ, C. et al. Detection of PCV3 in German wild boars. Virology Journal, v.16, p.1-7, 2019. Available from: <https:// virologyj.biomedcentral.com/articles/10.1186/s12985-019-11339>. Accessed: Mar. 15, 2021. doi: 10.1186/s12985-019-1133-9.

RINCÓN MONROY, M. A. et al. Detection and molecular characterization of porcine circovirus type 2 from piglets with porcine circovirus associated diseases in Colombia. Virology Journal, v.11, p.1-11, 2014. Available from: <https://virologyj. biomedcentral.com/articles/10.1186/1743-422X-11-143>. Accessed: Mar. 15, 2021. doi: 10.1186/1743-422X-11-143.

RODRIGUES, I. L. F. et al. Retrospective study of porcine circovirus 3 (PCV3) in swine tissue from Brazil (1967-2018). Brazilian Journal of Microbiology, v.51, p.1391-1397, 2020. Available from: $<$ https://link.springer.com/article/10.1007/s42770-020-00281-6>. Accessed: Mar. 15, 2021. doi: 10.1007/s42770-020-00281-6.

SAPORITI, V. et al. Similar frequency of porcine circovirus 3 (PCV-3) detection in serum samples of pigs affected by digestive 
or respiratory disorders and age-matched clinically healthy pigs. Transboundary and Emerging Disease, v.67, p.199-205, 2020. Available from: <https://onlinelibrary.wiley.com/doi/ full/10.1111/tbed.1334>. Accessed: Mar. 15, 2021. doi: 10.1111/ tbed.13341.

SARAIVA, G. L. et al. Retrospective detection and genetic characterization of porcine circovirus $3(\mathrm{PCV} 3)$ strains identified between 2006 and 2007 in Brazil. Viruses, v.11, p.1-11, 2019 Available from: <https://www.mdpi.com/1999-4915/11/3/201>. Accessed: Mar. 15, 2021. doi: 10.3390/v11030201.

SEGALÉS, J. Porcine circovirus type 2 (PCV2) infections: clinical signs, pathology and laboratory diagnosis. Virus Research, v.164, p.10-19, 2012. Available from: <https://www.sciencedirect.com/ science/article/pii/S0168170211004011>. Accessed: Mar. 15 2021. doi: 10.1016/j.virusres.2011.10.007.

SEGALÉS, J. et al. The natural history of porcine circovirus type 2: from an inoffensive virus to a devastating swine disease? Veterinary Microbiology, v.165, p.13-20, 2013. Available from: $\quad<$ https://www.sciencedirect.com/science/article/pii/ S0378113513000424>. Accessed: Mar. 15, 2021. doi: 10.1016/j. vetmic.2012.12.033.

STADEJEK, T. et al. First detection of porcine circovirus type 3 on commercial pig farms in Poland. Transboundary and Emerging Diseases, v.64, p.1350-1353, 2017. Available from: <https:// onlinelibrary.wiley.com/doi/full/10.1111/tbed.12672>. Accessed: Mar. 15, 2021. doi: 10.1111/tbed.12672.

TEMEEYASEN, G. et al. Pathogenicity and immune response against porcine circovirus type 3 infection in caesarean-derived, colostrum-deprived pigs. Journal of General Virology, v.102, p.1-16, 2021. Available from: $<$ https://www.microbiologyresearch. org/content/journal/jgv/10.1099/jgv.0.001502>. Accessed: Mar. 15, 2021. doi: 10.1099/jgv.0.001502.

TOCHETTO, C. et al. Full-Genome Sequence of Porcine Circovirus type 3 recovered from serum of sows with stillbirths in Brazil. Transboundary and Emerging Diseases, v.65, p.5-9, 2018. Available from: <https://onlinelibrary.wiley.com/doi/abs/10.1111/tbed.12735>. Accessed: Mar. 15, 2021. doi: 10.1111/tbed.12735.

VARELA, A. P. M. et al. Complete genome characterization of porcine circovirus 3 recovered from wild boars in Southern Brazil. Transboundary and Emerging Diseases, v.00, p.1-8, 2020. Available from: <https://onlinelibrary.wiley.com/doi/full/10.1111/ tbed.13679> . Accessed: Mar. 15, 2021. doi: 10.1111/tbed.13679.

WANG, Y. et al. Genetic diversity and prevalence of porcine circovirus type 3 (PCV3) and type 2 (PCV2) in the Midwest of the USA during 2016-2018. Transboundary and Emerging Diseases, v.67, p.1284-1294, 2020. Available from: <https:// onlinelibrary.wiley.com/doi/abs/10.1111/tbed.13467>. Accessed: Mar. 15, 2021. doi: 10.1111/tbed.13467. 